\title{
De passivas a heroínas, de órfãs a cangaceiras eróticas: um breve debate teórico sobre as mulheres sertanejas na pornochanchada
}

\author{
From passive women to heroines, from orphans to erotic cangaceiras: a brief \\ theoretical debate on backland women in Brazilian pornochanchada \\ Caroline de Araújo Lima \\ https://orcid.org/0000-0003-4069-4302 \\ Universidade do Estado da Bahia
}

\begin{abstract}
Resumo: As representações das cangaceiras no cinema nacional é o centro desse artigo. O objetivo do trabalho é a partir da teoria feminista do cinema problematizar a imagem feminina como objeto passivo para o olhar do sujeito masculino. Tal problematização e as contribuições da teoria feminista do cinema serão utilizados para a breve análise do filme As Cangaceiras Eróticas (1974), que na sua narrativa trouxe uma contraposição ao modelo hegemônico cinematográfico em relação a definição dos personagens masculinos como o ego ideal do espectador, a expressão da virilidade e das mulheres como as reguladoras das tensões, aquela que se apaixona pelo mocinho e torna-se propriedade do mesmo. O filme a ser analisado é uma pornochanchada: As Cangaceiras Eróticas. A obra é considerada uma comédia e um thriller de aventura, onde o enredo gira entorno do cotidiano de um bando de cangaceiros ambientados com alguns elementos da cultura nordestina. A história se passa no ambiente inóspito do sertão, no qual, um grupo de mulheres decidem entrar para o Cangaço motivadas por vingança e para não se tornarem escravas de "empresários ou de marido". Estas personagens (a cangaceiras, os(as) sertanejos(as)) são o objeto de análise do trabalho. A breve discussão teórica que pautará a análise fílmica partiu dos questionamentos do movimento feminista a esse modelo de cinema, que produziu uma disputa entorno das relações de gênero nas produções cinematográficas. O artigo fará uma breve exposição do contexto histórico que tais questionamentos ganham destaque, pós maio de 1968, onde o ceticismo em relação as teorias totalizantes colocou a produção cinematográfica ao lado de questões alinhadas aos direitos sexuais e reprodutivos, de combate ao racismo e a defesa do amor livre.
\end{abstract}

Palavras-chave: Cangaceiras. Cinema. Representações sociais.

Abstract: The representations of cangaceiras in the national cinema is the center of this article. The objective of the work is from the feminist theory of cinema to problematize the female image as a passive object for the male subject's gaze. Such problematization and the contributions of the feminist theory of cinema will be used for the brief analysis of the film The Erotic Cangaceiras (1974), that in its narrative brought a counterposition to the hegemonic cinematographic model in relation to the definition of the masculine personages like the ideal ego of the spectator, the expression of virility and women as the regulators of tensions, the one that falls in love with the good guy and becomes the property of the same. The movie to be analyzed is a pornochanchada: The Erotic Cangaceiras. The play is considered a comedy and an adventure thriller, where the plot revolves around the daily life of a band of cangaceiros set with some elements of the Northeastern culture. The story takes place in the inhospitable environment of the hinterland in which a group of women decide to enter Cangaço, motivated by revenge

Esta obra está licenciada sob uma Creative Commons - Atribuição 4.0 Internacional 
and not to become slaves of "businessmen or husband." These characters (the cangaceiras, the sertanejos (as)) are the object of analysis of the work. The brief theoretical discussion that will guide the film analysis started from the feminist movement's questioning of this model of cinema, which produced a dispute surrounding gender relations in cinematographic productions. The article will give a brief exposition of the historical context that these questions are highlighted, after May 1968, where skepticism in relation to totalizing theories has placed cinematographic production alongside issues that are aligned with sexual and reproductive rights, against racism and defense of free love.

Keywords: Cangaceiras. Cinema. Social representations.

\section{Introdução}

A história das mulheres foi por muito tempo secundarizada, contribuindo na constituição de sua imagem associada ao desequilíbrio entre a mulher delicada e dependente do apoio masculino, e a outra, realista e independente. Concretamente, o patriarcado $^{1}$ e o machismo ${ }^{2}$ consolidaram a imagem da mulher e do feminino a fragilidade e a sua submissão ao masculino. Essa caracterização marcou a presença das mulheres no cinema, principalmente no cinema hegemônico - o hollywoodiano.

As lutas pelos direitos das mulheres e o Movimento Feminista questionarão essa caracterização do feminino, além de produzir uma teoria do cinema que romperia com a ordem patriarcal dominante. Diante disso, o objetivo do artigo é a partir da teoria feminista do cinema problematizar a imagem feminina como objeto passivo para o olhar do sujeito masculino, a partir da análise do filme As Cangaceiras Eróticas (1974).

A obra analisada é considerada uma comédia e um thriller de aventura, sua história se passa no ambiente inóspito do sertão, no qual, um grupo de mulheres decidem entrar para o Cangaço motivadas por vingança e para não se tornarem escravas de "empresários ou de maridos". Estas personagens (as cangaceiras, os/as sertanejos/as) são o objeto do trabalho.

\section{O feminino no cinema e a produção de uma teoria feminista do cinema}

Para Joanice Levy (2010) o olhar do cinema era, em certa medida e ainda é, masculino por ser hegemonizado por homens. A partir das lentes de gênero a autora apontou que o olhar hegemônico também estaria presente nas visões das mulheres, que consequentemente masculinizaram o seu olhar. Historicamente o cinema marginalizou as mulheres, pois na divisão social do trabalho foram consideradas mão de obra barata e responsáveis pelos serviços domésticos. O cinema era o espaço das técnicas e da tecnologia avançada, dos engenheiros, químicos e físicos, da mão de obra especializada: a dos homens. O cinema não era lugar para o feminino, de acordo com John Berger (1977, p. 56-57),

nascer mulher é vir ao mundo dentro de um espaço definido e confinado, à guarda do homem. Os homens agem, as mulheres aparecem. Os homens olham para as mulheres. As mulheres veem-se a serem vistas. Isto determina não só a maioria das relações entre homens e mulheres como também as relações das mulheres consigo

\footnotetext{
${ }^{1}$ Designa uma formação social onde os homens detêm o poder, o domínio é masculino. In: HIRATA, et al, 2009.

2 Está baseado e associado a características masculinas, virilidade, força física que coloca a mulher enquanto submissa e frágil, relação de superioridade masculina em relação as mulheres. In: HIRATA, et al, 2009.
} 
próprias.

Partindo da assertiva de Berger (1977) e das análises de Levy (2010), observouse que a massificação do cinema legou as mulheres o lugar da imagem e aos homens os donos do olhar. Desse modo, por muito tempo a produção cinematográfica teve como base o falocentrismo ${ }^{3}$, atribuindo à mulher a condição de vítima, daquela que busca 0 falo ou seja, as desigualdades sociais e de gênero também se expressam no cinema.

De acordo com Holanda e Tedesco (2017, p. 10) "as personagens eram subjugadas por estereótipos que as aprisionavam ao lugar de mães e donas de casa, valorizadas pela juventude, beleza e habilidade de sedução que deveriam ser eternas". As personagens que fugiam desse padrão, a exemplo das solteiras, profissionalmente independentes e intelectuais eram representadas como as feias ou as vilãs, ou aquelas que abriam mão de sua independência pelo amor romântico de um homem.

Esse espaço no qual as mulheres foram colocadas e o cinema patriarcal/ falocentrico foram questionados pelo movimento feminista, produzindo uma disputa entorno das relações de gênero nas produções cinematográficas. Sendo assim, na década de 1970 as mulheres começam a conquistar espaço nos filmes, como protagonistas, produtoras, roteiristas e diretoras.

De acordo com Veiga (2017) entre 1970 e 1980 um discurso crítico sobre a situação desprivilegiada das mulheres nos filmes e na sociedade ganhou espaço no cinema, a denúncia ecoou em diversas partes do mundo e influenciou tanto a teoria do cinema quanto a produção cinematográfica. Essa década também foi marcada no Brasil pela Ditadura Militar, a censura e a resistência feminista.

Nesse contexto apontado por Veiga, o feminismo cinematográfico conquistou espaço, tal como o feminismo de um modo geral, tomando como ponto de partida textos "protofeministas" como A roomof one's own, de Virginia Woolf e o Segundo Sexo, de Simone de Beauvoir (ibidem, p. 193). Havia no final da década de 1960, um debate teórico sobre a emancipação das mulheres e dos negros em relação a um paternalismo que procurava impor às mulheres e à população negra "seu lugar na sociedade", isto é, as relações de poder pautavam a construção das diferenças sociais e as hierarquias de gênero e racial, que nesta época estavam sendo questionadas e rompidas. Segundo Stam:

A teoria feminista do cinema também deflagrou uma nova reflexão sobre o estilo (a
questão da écriture feminina), sobre as hierarquias e processos de produção
industriais (a histórica relegação da mulher a funções montadora, uma espécie de
"custureira, e continuísta, uma espécie de "arrumadeira") e sobre a teoria de
espectatorialidade (o olhar feminino, o masoquismo, a masquerade). (Stam, 2003,
p. 195)

De fato, a teoria feminista no cinema rompeu com a ideia do "homem é o condutor e a mulher a passageira" (Stam, 2003, p. 197). E finalmente: o que é uma mulher? (Beauvoir, 1949, p. 193). Ao longo do século XX, as respostas partiam inicialmente de um elemento dito como "natural": o sujeito que procria, a verdadeira mulher é a figura maternal. Essa percepção do ser mulher, de acordo com Maria Rita Kehl, foi fruto da

insistência com que pensadores e cientistas afirmaram que o único lugar digno para

\footnotetext{
${ }^{3}$ As relações de poder estão concentradas em ter um pênis. Comportamentos baseados na ideia da superioridade masculina, na qual falo representa o valor significativo fundamental. In: GALLOP, 2001.
} 
a mulher seria o lar e que sua tarefa mais valiosa seria aquela para a qual sua natureza a preparou - a maternidade - pode ser vista hoje, como reação a um início de desordem social que se esboçou no século XVII e tornou-se alarmante no século $\mathrm{XVIII}$, quando a Revolução Francesa destruiu as fronteiras que no Antigo Regime separavam a esfera pública da vida privada. (Kehl, 2016, p. 42)

Ou seja, ser mulher não é algo dado ou natural, é uma construção social. Essa construção do ser mulher, do feminino constituiu um habitus do ser mulher, um conjunto de práticas e ideologias que justificariam a submissão da mulher pelo Outro - e esse seria o sujeito que representasse o masculino. Para Pierre Bourdieu, esse habitus constituiu a dominação masculina, pois

a visão androcêntrica se impõe como neutra e não tem necessidade de se enunciar, visando sua legitimação. A ordem social funciona como uma imensa máquina simbólica, tendendo a ratificar a dominação masculina na qual se funda: é a divisão social do trabalho, distribuição muito restrita das atividades atribuídas a cada um dos dois sexos, de seu lugar, seu momento, seus instrumentos. (Bourdieu, 2002, p. 18)

Compreende-se aqui que o habitus mulher relaciona-se ao processo de sua dominação pelo masculino e da ideia do feminino enquanto fragilidade, de acordo com Maria Rita Kehl,

[...] dito de outra forma, a inscrição dos sujeitos, homens ou mulheres, no discurso do Outro, não é rigidamente fixada. Ao longo da história, ela passa por modificações que, se não alteram a estrutura da linguagem, certamente alteram o uso da língua e, com isso, os lugares que a cultura confere aos sujeitos. Que as mulheres, por exemplo, ocupem o lugar da inocência ou do pecado, da castração ou da onipotência, da sexualidade desenfreada e ameaçadora que ser submetida aos freios do pudor e da castidade [...] depende em última instancia, das práticas falantes. Estas se modificam sutil e lentamente em função dos deslocamentos sofridos pelos agentes sociais ao longo da história - deslocamento da classe, gênero, inserção junto ao poder etc., os quais, estes sim, escapam ao controle das vontades individuais. (Kehl, 2016, p. 20)

O lugar do Outro seria fruto das práticas falantes e os agentes que a constituem determinam os discursos que alimentam o inconsciente coletivo. O discurso do Outro tornou-se o inconsciente dos sujeitos (homens e mulheres). Sobre isso, Michel Foucault (2013) apontou que esses discursos que fundamentam os lugares dos indivíduos são intervenções das instituições, ele "está na ordem das leis; que há muito tempo cuida de sua aparição [...] se lhe ocorre ter algum poder, é de nós, só de nós, que lhe advém" (Foucault, 2013, p. 07).

Essas instituições foram constituídas na sociedade moderna, segundo Emile Durkheim (1983), com a função de orientar os sujeitos. A definição dos papeis sociais organizam e harmonizam a sociedade, a expressão de poder da intervenção das instituições, para Maria Kehl, está explicita na primeira inscrição que nos é dada ao nascermos, que seria a marca da sexualidade. Antes de nascermos nos sãos impostos as identidades do ser menino e o ser menina.

Essas marcações indenitárias e a definição de feminino influenciou o cinema por muito tempo. Para Joanice Levy (2010), a teoria feminista reposicionou o olhar feminino (female gaze) diante das representações das mulheres construídas no cinema. Para Mulvey (2003), a mulher significava e representava nas telas o desejo masculino,

[...] o cinema constrói o modo pelo qual ela [a mulher] deve ser olhada, dentro do 
próprio espetáculo. Jogando com a tensão existente entre o filme enquanto controle da dimensão do tempo (montagem, narrativa), e o filme enquanto controle das dimensões do espaço (mudanças em distância, montagem), os códigos cinematográficos criam um olhar, um mundo e um objeto, de tal forma a produzir uma ilusão talhada à medida do desejo. (Mulvey, 2003, p. 452)

Se a montagem, a narrativa e a trilha sonora nos teletransporta no tempo e no espaço numa sala de cinema, essa indústria constituiu também modelos identitários, um fabricante de egos, de acordo com a Mulvey.

Mas se o olhar masculino submete as mulheres ao lugar da vítima e da expressão do desejo do homem, esse mesmo olhar, de acordo com Fredric Jameson (2001), trouxe também uma dimensão utópica. De acordo com o autor, sem essa dimensão a cultura hegemônica não alcançaria as mulheres. Assim, Levy (2010) apontou a necessidade de aprofundar essa discussão, ao compreender o "olhar feminino" como um ponto de vista ancorado em práticas discursivas que reposicionam o lugar da mulher e do homem na sociedade, contribuindo no debate sobre o lugar do feminino e do masculino no cinema, da mesma forma que a ressignificação dos mesmos, além de contribuir na construção da crítica ao modelo hegemônico do olhar no cinema: masculino e heteronormativo.

Mulvey e Levy partiram de uma leitura psicanalítica do cinema, com o objetivo de analisar como o cinema revela, reflete e produz representações a partir do controle da imagem, da formação a partir de determinações sociais de um olhar erótico e do espetáculo, "a teoria psicanalítica é, desta forma, apropriada aqui como um instrumento político demonstrando o modo pelo qual o inconsciente da sociedade patriarcal estruturou a forma do cinema" (Mulvey, 2003, p. 437).

A leitura psicanalítica evidenciou o paradoxo do falocentrismo e a castração da mulher, o sistema que consolidou a imagem da mulher enquanto vítima, tornou a imagem feminina como uma memória ligada a maternagem e a busca pela compensação da ausência do falo. Nesse sentido, no cinema a mulher aparece como portadora de significado e não como produtora de significado. A masculinização do cinema colocou o homem no comando linguístico, exprimindo suas fantasias e a mulher no lugar da submissão. Esse sistema só foi rompido quando as mulheres produziram uma teoria explicativa, que identificaria a misoginia e o patriarcado no cinema.

A crítica da teoria feminista provocou mudanças na produção cinematográfica, mas não o suficiente. Para Veiga (2017) no contexto marcado pelo avanço do regime ditatorial, no qual, a esquerda constituía-se campo anti-imperialista e de resistência na produção cinematográfica, este mesmo cinema contraditoriamente resistia reconhecer os trabalhos feministas no cinema. A justificativa, segundo a autora, por considerar o feminismo um movimento pequeno-burguês, ou seja, o novo cinema latino-americana já nascia velho e nada disposto a romper com suas tradições, ao se negarem a discutir a hierarquia e as relações de gênero desiguais para as mulheres na sociedade faziam a opção de naturalizar tais desigualdades.

Para Mulvey (2003) essas desigualdades construíram uma divisão heteronormativa do trabalho no cinema, pois a figura masculina não suporta o peso da objetificação sexual, muito menos olhar para um outro homem se exibindo na tela. Desse modo, o lugar das mulheres nos filmes está dentro das estruturas psíquicas que sustentam essa narrativa, o homem ser ativo e a mulher ser passivo.

De acordo com a autora a ausência do pênis tornou o ícone mulher um incomodo, o controle de seu corpo e da sua sexualidade acabou dando sentido a 
narrativa, o prazer visual do assistir, o controle dos corpos e a sua exibição, ou seja, "a beleza da mulher enquanto objeto e o espaço da tela se unem; ela não é mais a portadora da culpa e sim um produto perfeito, cujo corpo, estilizado e fragmentado nos clouse-ups, é o conteúdo do filme e o recipiente direto do olhar do espectador" (Mulvey, 2003, p. 448).

Considerando essa breve discussão teórica observou-se que o cinema acabou reproduzindo as normas sociais e institucionais que definiram os papeis de homens e mulheres, produzindo representações sociais do feminino, logo, também das cangaceiras. Mas, as cangaceiras não são sujeitas isoladas, fazem parte da história do sertão, do povo sertanejo e do mundo rural, são parte do imaginário sobre o Nordeste. Diante disso, para compreendermos o lugar dessas mulheres nas pornochanchadas, antes precisamos localizar o Nordeste e o rural no cinema.

\section{O rural no cinema e a invenção do Nordeste}

As temáticas rurais foram pautadas no cinema nacional numa conjuntura de busca pelo processo revolucionário no país, ainda pautado nas experiências russa e cubana. De acordo com Célia Tolentino (2001) essas perspectivas ainda estavam distantes da realidade e especificidades das mazelas brasileiras que tinham como fundamento o seu capitalismo próprio. Nesse momento, para a esquerda e seus intelectuais - ligados ao PCB e/ou ISEB - o rural brasileiro apresentava-se como précapitalista e feudal, "esse mesmo rural comportava o camponês imaculado do imperialismo cultural, que por isso, era o verdadeiro portador da cultura nacional" (Tolentino, 2001, p. 136).

De acordo com Albuquerque Jr. (2006), elementos como a literatura de Graciliano Ramos e Jorge Amado, na década de 1930, bem como a de Rachel de Queiroz e José Lins Rêgo, influenciaram certamente esses cineastas. Partindo de suas obras, segundo Albuquerque, os cineastas tomaram o Nordeste como exemplo privilegiado da miséria, da fome e do subdesenvolvimento.

A produção artística do grupo denominado de "esquerda", para o autor, acabou reforçando imagens que ligavam a região ao discurso da seca e do abandono. Seria uma visão mítica de Nordeste que, mesmo invertendo o discurso, denunciando as suas mazelas, permanecem reforçando o imaginário construído a região na década de 1930, da seca, da fome, da miséria, do messianismo e do cangaço.

Se inventou um Nordeste com uma imagem cristalizada, na qual sua existência sem coronéis, sem os santos e a religiosidade popular, e sem a seca, não seria possível. Pensar um sertão verde, não seria admissível, pois o verdadeiro Nordeste, construído no território brasileiro, deveria ter características próprias, deveria ser mestiço, seco e messiânico. Seus personagens e seu ambiente ganharam novos aspectos, e um novo discurso, mas continuavam os mesmos. Pensando o cangaceiro no Cinema Novo:

O mesmo cangaceiro que era visto pelos tradicionalistas como o justiceiro dos pobres, como o homem integrado a uma sociedade tradicional e que se rebelava por ser vítima da sociedade burguesa, tornar-se-á, no discurso e obras artísticas de intelectuais ligados à esquerda, um testemunho da capacidade de revolta das camadas populares e símbolo da injustiça da sociedade burguesa, ou uma prova da falta de consciência política dos dominados, uma rebeldia primitiva e malorientada, individualista e anárquica. (Albuquerque Jr., 2006, p, 194)

Para os intelectuais urbanos, 
O Nordeste, como território da revolta, foi criado basicamente por uma série de discursos acadêmicos e artísticos. Discursos de intelectuais de classe média urbana. Uns interessados na transformação, outros na manutenção da ordem burguesa. (Idem)

Para Albuquerque Júnior, personagens como o cangaceiro, o beato, o jagunço, os coronéis tornaram-se elementos típicos de uma sociedade que morria. Daí o debate em torno do arcaico e do moderno, da necessidade da morte de uma sociedade bárbara para abrir os caminhos para os novos mitos da sociedade civilizada. Lampião (18981938), Antônio Conselheiro (1830-1897), Padre Cícero (1844-1944) abrem passagem para "Delmiro Gouveia, o pioneiro da industrialização da região, o nacionalista que enfrentou o imperialismo inglês, que trouxe a energia elétrica para o sertão seco, que domou com a técnica a fúria da natureza" (Albuquerque Jr., 2006, p, 195).

Segundo ao autor, para os intelectuais marxistas o cangaço, o messianismo e o coronel eram determinados por seus aspectos socioeconômicos. O cangaceiro e o beato eram heróis dos marginalizados, exemplos de luta contra a opressão. Entre as décadas de 1940 e 1950, os personagens cangaceiros, jagunços e coronéis eram símbolos das forças sociais, formadores de mitos de uma região, o Nordeste e camponês eram quase a mesma coisa.

Se as décadas de 1940 e 1950 foram marcadas pela industrialização do cinema no Brasil, as temáticas rurais como expressão de originalidade e brasilidade também foram características da história do cinema nacional. De acordo com Albuquerque Júnior (2006) e Vieira (2010) os roteiros dos filmes do gênero de cangaço estruturaram-se nos moldes do faroeste hollywoodiano, mas isso não invalidava a forte presença da cultura brasileira no Nordeste, já que

se os americanos possuem seus westerns imortalizados pela figura do cowboy, o Nordeste do Brasil possui os cangaceiros, tema que há muito tempo faz parte do cenário cinematográfico brasileiro, tendo se tornado um gênero bastante singular no cinema nacional, conhecido como a "versão tropical do western americano". (Vieira, 2007, p. 23)

Se para Vieira os filmes de cangaço marcaram a entrada do Brasil na indústria cinematográfica no auge do bang bang, para Tolentino a temática rural foi eleita pelo cinema engajado do início da década de 1960, como romântico e expressão da nossa originalidade e dos assuntos tipicamente brasileiros, para Wills Leal (1982)

O filme de cangaço criou, em pouco mais de uma década, um verdadeiro ciclo, o único sobre homens e acontecimentos nordestinos. Foi o fenômeno cangaço que permitiu num cinema, tão sem diretrizes como o brasileiro (até mesmo com o surgimento do chamado cinema novo), a explosão de uma série de filmes com estrutura estético-dramática e visão sócio-política especiais. (Leal, 1982, p. 89)

De acordo com o autor, os filmes com temática rural e do cangaço consolidou um gênero e uma estética, entretanto, esse herói marginal brasileiro - o cangaceiro estaria obedecendo à tendência dos filmes do estilo western, à moda das produções cinematográficas hollywoodianas. Esse gênero nordestern de acordo com Andrade (2007), também construiu um Nordeste imagético e a sua negação.

A brasilidade estaria localizada no campo e nos seus atores/atrizes, mas também representava o imaginário sobre o sertão, já que a produção e montagem de películas sobre cangaço, ao menos um número significativo de filmes, tiveram por locação o interior de São Paulo, a cidade de Itu. De acordo com Caroline Santos (2010) a 
construção de sertão e do Nordeste partiu inicialmente do imaginário paulistano, já para Leal (1982) a construção imagética do mundo sertanejo no cinema, apresentou alguns elementos das suas contradições,

o filme de cangaço tem sido a história de ação do latifúndio contra o vaqueirolavrador, o homem que, forçado pelas circunstancias, se torna criminoso, passa a usar chapéu meia lua e, em bandos, sai pelo campo e vilas matando, roubando e tentando viver. O latifúndio é representado pela figura do Coronel e sua força legal (a polícia), ou sua própria força (seus cabras). Só em casos bastante especiais é que o filme do ciclo enfoca noutro prisma. (Leal, 1982, p. 90)

Para o autor apesar do fundo sócio-político do fenômeno social, este elemento não foi caracterizado nos filmes nordestern. O movimento do Cinema Novo ao contrário dos filmes western brasileiros, pautou com maior profundidade a questão do latifúndio trazendo uma nova perspectiva de cangaço e a estética da fome. As obras do Cinema Novo referenciavam-se em um projeto revolucionário para o Brasil, a partir da ficção tentavam chamar a atenção para as contradições sociais.

O nordestern e o Cinema Novo trouxeram leituras distintas do sertão e do Nordeste, mas com o golpe e a instalação de uma Ditadura Militar a produção cultural no Brasil enfrentou diversas dificuldades, nesse momento um outro gênero cinematográfico se destacou: as pornochanchadas. Lotaram as salas de cinema com seu erotismo escrachado e seus jogos de driblar a censura no regime autoritário no Brasil, evidenciando as contradições da sociedade brasileira, sendo esta conservadora nos costumes, porém, paralelamente principal público consumidor do gênero cinematográfico.

\section{A subversão das cangaceiras na Pornochanchada}

Do fim dos anos 1960 ao início da década de 1980, houve uma eclosão de filmes com fortes tonalidades eróticas no Brasil. Segundo Brandão e Sousa (2017) tais filmes foram erroneamente homogeneizados sob o rótulo de pornochanchada, foram comparadas as chanchadas da década de 1940 e desqualificado por contas dos baixos orçamentos, o prefixo pornô de acordo com as autoras foi usado equivocadamente, pois nem todos os filmes tinham conteúdo pornográfico, além disso

O fato é que as pornochanchadas e os filmes eróticos mais "sérios" foram uma resposta às transformações sociais que ocorreram na sociedade brasileira, que, ao final dos anos 1960, passava por uma verdadeira revolução sexual. Ao lado das lutas políticas que marcaram a segunda metade da década de 1960, que incluíam a resistência à ditadura militar, o questionamento da sexualidade abriu a possibilidade de um espectro mais amplo de experiências. (Brandão; Sousa, 2017, p. 136)

De acordo com as autoras as pornochanchadas e o cinema erótico da época expressaram de diversas formas da celebração das novas configurações sociais. Nesse momento "a sexualidade passou a ser vista como um campo de batalha para a redefinição da cultura e da sociedade brasileira" (Idem, p. 137). Essa batalha foi travada numa conjuntura de ditadura militar e censura.

A censura cortava cenas, textos e forçava os cineastas a pensar outras formas de transgredir, sem perder a criatividade. As barreiras impostas pelos governos militares fizeram com que a pornochanchada fosse o gênero mais produzido no país, já que 
a comédia, elemento sempre de muito sucesso em nossa cinematografia, como bem comprovam as chanchadas dos anos 40 e 50, aliou-se ao erotismo com tanto sucesso que essa reunião se tornou verdadeiramente, para o grande público, sinônimo de cinema brasileiro. Dizer, a partir de então, que o cinema nacional "só mostrava mulher pelada", tornou-se lugar comum. (Sales Filho, 1995, p. 67)

Esses filmes sofreram com o preconceito e a moralização da arte, de acordo com Brandão e Sousa (2017), o olhar conservador e as críticas que desqualificaram as pornochanchadas vieram inclusive dos críticos considerados progressistas que "negaram a esses filmes eróticos qualquer mérito político ou artístico" (p. 137).

Para Fernanda Pessoa (2018) desprezar as pornochanchadas é desconsiderar parte importante da história do cinema, pois em suas entrelinhas tocaram em temas importantes como tortura, drogas, crise econômica e empoderamento feminino. Para Klanovicz (2016, p. 63),

há várias leituras sobre as pornochanchadas, que vão desde seus aspectos técnicos, passando pelo enquadramento estético em meio aos gêneros fílmicos, as biografias de artistas e técnicos envolvidos, as trajetórias de produção, a sua politização inevitável em meio ao regime autoritário e aos debates e dilemas morais da sociedade brasileira e, mais recentemente, a discussão ligada aos estudos de gênero e história.

Segundo a autora os dilemas morais presentes nas obras, apesar de se contrapor ao patriarcado, limitavam-se ainda na manutenção da lógica heteronormativa. Outro elemento identificado pela autora foi a forma que o governo autoritário analisava, por meio de seus censores, estes filmes. Identificou-se que preocupação da censura estava com as palavras de baixo calão e algumas cenas de sexo, deixando que críticas ao Regime Militar permanecessem nos filmes, apontando a necessidade de analisarmos o lugar da pornochanchada e suas relações com os organismos de controle do Estado.

Além de qualquer visão funcionalista sobre a utilização desses filmes como apaziguadores das massas, ou da expansão proporcionada pelos incentivos do Estado, um outro importante motivo pode explicar o sucesso das pornochanchadas: o da própria identificação do público com os conteúdos presentes. (Sales Filho, 1995, p. 68)

O público se identificava com os filmes, segundo Abreu (2006) essa identificação somado ao custo-benefício, o tempo curto de produção e como elemento central o erotismo, tornaram a pornochanchada sinônimo de lucro. Essa receita lucrativa produziu dois filmes do ciclo do cangaço: As Cangaceiras Eróticas (1974) e A llha das Cangaceiras Virgens (1976) ambas com a Direção de Roberto Mauro. Como foi tratado por Célia Tolentino (2001), o movimento cultural da década de 1960 e a imersão dos movimentos do campo colocaram o rural como tema na produção cinematográfica, pois trazia nele o sumo do que seria a brasilidade, logo justificando a permanência da temática em gêneros cinematográficos diversos.

Em ambos os filmes as mulheres são protagonistas, contudo, para Laurentis (1993) mesmo sendo um contra discurso ao modelo hegemônico de cinema, o filme pornográfico foi produzido para os homens, e só para eles. A análise prévia do filme As Cangaceiras Eróticas apontou que esse gênero não rompia com o olhar masculino, mas nas suas entrelinhas as mulheres protagonizaram cenas de empoderamento, liberdade sexual e não se submeteram ao amor romântico.

As cenas iniciais do filme mostram um pouco do cotidiano do bando de 
cangaceiros, dançando, jogando e bebendo, nesse momento alguns elementos da cultura nordestina são evidenciadas. Do quebra pote ao xaxado a cultura sertaneja e nordestina são representadas nesse momento, além do gosto dos(as) cangaceiros(as)s pela dança e pela festa. O momento festivo é interrompido por Volantes que armaram uma tocaia contra o bando, nesse confronto apenas um cangaceiro sobrevive: Toneco. A partir disso os personagens centrais da trama começam a aparecer. Um outro dado importante do filme é o cenário.

Muitos dos filmes com a temática do cangaço foram produzidos no município de Itu em São Paulo, que de acordo com Tolentino (2001) e Caroline Santos (2010), seria o cenário mais próximo da ideia de sertão por conta da sua topografia rochosa ao longo da rodovia, pródiga em matacões de granito, lembrando o ambiente seco do Nordeste. Observou-se a permanência na década de 1970 da ideia de um sertão seco, definido como local de fome e miséria.

É nesse ambiente rochoso que se passa a história das meninas Jasmim e Deo, filhas do grande cangaceiro Quirino Leão que foi traído e morto na tocaia. As órfãs que encontrarão tutela com Toneco, que sobreviveu e mesmo ferido foi ao encontro das duas crianças para relatar o que aconteceu e levá-las para um lugar seguro. No diálogo entre Tio Toneco, Jasmim e Deo temos a primeira demarcação na hierarquia de gênero, ao demonstrar a dor da perda e o desejo de vingança, Deo é interpelada pelo tio, o qual, afirma "Você é valente, mas nasceu menina. Não é macho", ou seja, por ser menina não poderá vingar seu pai.

$\mathrm{Na}$ sequência Toneco leva as meninas para o orfanato de Padre Lara, orientando-as a não dizerem que são filhas de cangaceiros, e sim de um caixeiro viajante. Mas a menina ao se apresentar ao Padre confirma que é filha do "perigoso cangaceiro Quirino Leão", logo repercutindo na cidade e provocando a ida do delegado ao Orfanato para sugerir ao Padre Lara que entregasse as filhas de Quirino Leão ao reformatório, pois "elas trazem no sangue o cangaço". O padre se recusa, pois são "meninas normais".

Esse diálogo evidencia a continuidade da narrativa nordestern na obra de Roberto Mauro, do cangaceiro como sujeito sanguinolento e criminoso, uma anormalidade. Mas eram meninas e a violência não cabe a elas, a ideia de feminilidade logo é quebrada quando o Padre e a Freira analisam os desenhos produzidos pelas alunas, todas desenharam cangaceiras, mas Jasmim foi além desenhou N. Senhora com chapéu de cangaceiro. Aqui fica explicito como as personagens rompem com a ideia de feminilidade. As personagens Deo e Jasmim destacam-se pela coragem e pela ousadia, aqui ambas são sujeitas da história e portadoras de significados.

No filme há uma passagem de tempo de 10 anos e as matérias jornalísticas apontam para a presença de Cornélio Sabiá como o rei do cangaço. Toneco entra no bando de Cornélio na tentativa de vingar o amigo Quirino Leão e descobre os planos do bando de invadir o orfanato de Padre Lara para matar as irmãs Deo e Jasmim. Na cena seguinte o personagem tenta avisar o Padre, mas não consegue evitar o assassinato deste e da irmã Eustáquia.

Após o ataque as órfãs lideradas por Deo decidem vingar a morte do Padre e da Freira, agora como cangaceiras. No diálogo entre as personagens viver no cangaço era sinônimo de liberdade, pois o contrário disso significava "ser escravizada por empresários ou por maridos ciumentos". Num contexto de censura e de Ditadura Militar esse diálogo entre as personagens apontou nas entrelinhas o empoderamento feminino e o casamento como expressão da opressão contra as mulheres, sobre esses 
elementos Fernanda Pessoa (2018) chama atenção para essas entrelinhas, o corpo feminino e sua sexualidade foram usadas para driblar censores e garantir alguma crítica social ou narrativa progressista.

Nessa perspectiva, observou-se como as personagens vão deixando de ser as órfãs recatadas e passam a ser mulheres liberadas, tornando-se cangaceiras. Ao som da marchinha "Acorda, Maria Bonita", as jovens treinam tiro ao alvo e costuram suas roupas, deixando as roupas de chita de lado e passam a usar o couro, incorporando o figurino do movimento do cangaço, mas de forma sensual.

A troca de figurino evidencia o rompimento do ideal feminino, roupas recatadas - a mulher "cativa", e a passagem para a transgressão. No momento que as personagens fizeram a opção de entrar para o cangaço libertaram-se das amarras morais. O filme se passa na década de 1970, no auge do movimento feminista e das pautas relacionadas a liberdade sexual, para Seligman (2000, p. 77),

A pornochanchada apresenta um microcosmo do país. Claro que, na maioria das vezes, este universo só está disponível em uma leitura subliminar, já que a ditadura militar jamais permitiu uma crítica social clara nas telas. Também não era esse o objetivo principal dos filmes.

E de forma subliminar a entrada de Deo e das outras órfãs no cangaceirismo deram a elas o controle dos seus corpos, rompendo com o papel social, no qual, estavam predestinadas: "mães de família e donas de casa". O bando de Deo e Jasmim fizeram a opção pelo cangaço para serem livres e também por vingança, o objetivo do bando era capturar cangaceiros. Fica evidente que os vilões estão no bando de Cornélio Sabiá.

No decorrer da trama, Toneco é assassinado pelos homens de Cornélio Sabiá, mas antes de morrer conta para Deo e Jasmim que o cangaceiro foi responsável pela morte de seu pai, as cangaceiras então partem em busca de justiça. Em diálogo com o personagem, o religioso Pedro Pastor, este questionou como elas iriam caçar o bando de Cornélio Sabiá, pois nem as Volantes conseguiam vencê-los, as Cangaceiras respondem: "porque eles não tinham as armas delas". As cancageiras usavam o corpo e a sensualidade nas tocaias.

Na caça a Cornélio Sabiá as cangaceiras encontram alguns homens do bando do traidor, armam a tocaia matando-os e aprisionando um deles, o qual foi usado por elas sexualmente e depois o libertaram. E essa tática tornou-se uma característica das ações das cangaceiras, que ganharam fama e espaço nos jornais.

$\mathrm{O}$ fato de ter um bando comandado por mulheres causou espanto, as pessoas começam a sugerir que essas mulheres eram uma "assombração". Para outros, encontrá-las era motivo de alegria, os homens levados por elas têm o pênis medido e são usados como objetos sexuais. O diretor do jornal O Clarim, indignado com as atitudes das cangaceiras, cobrou providências ao delegado e, em praça pública, discursou em favor dos bons costumes. "São as noivas do Belzebu; do demônio; são filhas da puta" - termos usados contra as cangaceiras.

A indignação do jornalista se expressou na cena, na qual, junto com o Prefeito em praça pública discursaram "O Nordeste vive a maior crise moral da sua história! Estão sendo envergonhados do sul ao nordeste do país! Precisamos montar uma Cruzada! Sim uma cruzada contra essas 'cangaceiras sexuais'". Mulheres no cangaço e livres sexualmente significavam a desordem social, era um crime contra a honra e contra a moral cristã. 
Criou-se uma mobilização para acabar com as cangaceiras com a justificativa de defender as famílias, pois essas mulheres fanfarronas e poligâmicas ocuparam o lugar do masculino. Para Brandão e Sousa (2017) a ambiguidade estética e política das pornochanchadas, com todas as suas contradições, devem ser reconhecidos pela importância dada as personagens femininas. A exemplo da obra As Cangaceiras Eróticas, as atrizes se destacavam tanto por sua beleza e sensualidade, quanto por sua objetificação a partir do olhar masculino. De acordo com as autoras, "com uma marca fortemente impressa no imaginário nacional, essas atrizes confirmaram a ambiguidade de um cinema (e de toda uma sociedade) sobre quem a figura feminina exercia, ao mesmo tempo, fascínio e repulsa, ternura e violência (Brandão; Sousa, 2017, p. 137).

Nesse misto de ternura e violência a trama chega ao fim com o confronto entre as cangaceiras e o bando de Cornélio Sabiá, que culminou na prisão de alguns e na morte do cangaceiro. O delegado liberou as cangaceiras, pois não se prende "Lendas". Contudo exige que as mulheres dispersem o bando e não peguem mais em armas, Deo confirma que fará isso, pois "a vingança está cumprida". No decorrer da história outras motivações foram evidenciadas que justificaram a entrada das mulheres no cangaço e de sua permanência, já que no final do filme não ficou explicito que cumpririam com o acordo.

Segundo Seligman (2000), as pornochanchadas foram caracterizadas por produções de massa, que atraiam em sua grande maioria um público masculino oriundo da classe média. Para Bertolli Filho (2016), esses filmes representaram um dos poucos espaços de contestação da ordem, não havia nada mais transgressor que uma mulher no cangaço.

As Cangaceiras Eróticas foi um filme que tratou da emancipação feminina e de subjugação dos homens aos prazeres das mulheres, entretanto, no final o Estado impôs o retorno delas a "vida normal". O movimento do cangaço significou para suas participantes empoderamento e a constituição de outro modelo de família, esses elementos nos faz questionar: o filme foi produzido para o público masculino apenas?

Para Laurentis (1993, p. 118) "[...], a teoria do cinema como uma tecnologia social, uma relação entre a técnica e o social, só pode ser desenvolvida através de uma crítica permanente de suas ações discursivas e a partir da consciência da sua atual inadequação". Ou seja, o cinema é uma obra de arte, mas também produz representações sociais, sofre influências do contexto histórico e da conjuntura sóciopolítica, diante disso, é importante dialogar com os códigos que dão sentido as representações sociais, considerando o papel da teoria feminista do cinema em evidenciar o contraditório.

Se "o mundo social constrói o corpo como realidade sexuada e como depositário de princípios de visão e de divisão sexualizantes" (Bourdieu, 2002, p. 19), as pornochanchadas, possivelmente contribuíram para romper com essa lógica. $O$ filme de acordo com Vieira (2007) quebrou com a perspectiva machista, pois

o grupo de cangaceiras constitui um bando formado somente por mulheres, e que em nada se assemelha ao grupo formado pelos cangaceiros homens. Este sim, já implantava o terror no sertão há vários anos e não tinha escrúpulos para suas maldades. Era um grupo formado exclusivamente pelo sexo masculino, que não permitia a participação de mulheres e não acreditava na atuação delas dentro do banditismo. Esse pensamento machista desmorona quando a fama das cangaceiras passa a percorrer o sertão nordestino, e o que era tido como boato ganha feições reais. (Vieira, 2007, p. 213) 
A pornochanchada de Roberto Mauro e a sua narrativa evidencia um diálogo com um público diverso, não apenas o masculino. O cineasta que faleceu em 2004 aos 64 anos, foi um dos grandes nomes da pornochanchada brasileira, de todas as suas obras a crítica considerou As Cangaceiras Eróticas revolucionário e inovador, já que no título inverte-se a ordem dos fatores, tirando as mulheres do papel de vítimas para assumirem uma posição de controle, indo atrás de vingança e em busca da realização dos seus desejos.

\section{Algumas considerações}

O artigo é parte da pesquisa em andamento no Doutorado, logo, as considerações aqui expostas ainda são resultados prévios das análises fílmicas. Ao contrário dos filmes sobre o cangaço do gênero nordestern, na pornochanchada analisada identificou-se que as cangaceiras foram representadas como mulheres independentes e desprendidas das normas morais, são protagonistas. A pornochanchada não foi direcionada ao público masculino apenas, isso está presente na narrativa da obra, contudo, a sexualização e a objetificação das mulheres não foram rompidas.

Outro elemento: elas foram marginalizadas? A análise indica que não. São protagonistas e se destacam, porque a pornochanchada não segue o modelo hollywoodiano clássico. As análises prévias dos dados indicam que as pornochanchadas não seguem a lógica do modelo clássico hollywoodiano, foram filmes produzidos num contexto de censura e apresentaram uma narrativa que se contrapunha ao momento político vivido no país. Diante disso, não podemos desconsiderar o cinema como obra de arte, pois fragiliza a leitura da produção das representações sociais e do imaginário sobre as mulheres como protagonistas nos filmes sobre cangaço.

Um outro aspecto é a necessidade de a teoria feminista do cinema dialogar com outros campos do conhecimento, pois a teoria psicanalítica não deveria ser o único instrumento político para analisarmos o modo pelo qual o inconsciente da sociedade patriarcal se estruturou e como influenciou o cinema. Mulvey (2003) trouxe grande contribuição teórica, sem ela o cinema continuaria reproduzindo o machismo e a mulher como "O outro".

A análise dos dados indicou a possibilidade de contribuir com novos elementos para a teoria feminista do cinema, apontou para a necessidade de localizar as pornochanchadas no contexto da ditadura militar e não as reduzir a comédias sem nenhuma expressão política, também a importância de identificar como o feminino cangaço foi produzido no cinema nacional, para analisarmos as representações sociais sobre as cangaceiras nos filmes.

\section{Referências}

ALBUQUERQUE Jr. Durval Muniz de. A Invenção do Nordeste e Outras artes. $3^{\text {a }}$ ed. São PaulolRecife: CortezlMassangana, 2006.

ABREU, Nuno César. Boca do Lixo: cinema e classes populares. Campinas: Editora da Unicamp, 2006.

ANDRADE, Matheus José Pessoa de. A Saga de Lampião pelos caminhos discursivos do cinema brasileiro. Dissertação (Mestrado em Letras). Paraíba: UFPB/PPG, 2007. 
BERGER, John. Modos de Ver. Lisboa: Edições 70, 1972.

BRANDÃO, Alessandra Soares; SOUSA, Ramayana Lira de. Cassandra Rios e o Cinema Erótico brasileiro: autoria e performatividade. 131-144. In: HOLANDA, Karla; TEDESCO, Marina, Cavalcanti (org). Feminino e Plural: mulheres no cinema brasileiro. Campinas-SP: Papirus, 2017.

BERTOLLI FILHO, Claudio. Um confronto esquecido: pornochanchada $x$ moral $e$ civismo. In: Pornochanchando: em nome da moral, do deboche e do prazer.

BERTOLLI FILHO, Claudio; AMARAL, Muriel Emídio Pessoa do (organizadores). São Paulo: Cultura Acadêmica, 2016.

BERNARDET, Jean-Claude. Cinema brasileiro: propostas para uma história. São Paulo: Companhia das Letras, 2009, p. 18-36.

BAUDELAIRE, Charles. Sobre a Modernidade. São Paulo: Ed. Paz e Terra, 1996.

BOURDIEU, Pierre. A Dominação Masculina. 2.ed. Rio de Janeiro: Bertrand Brasil, 2002.

BUTLER, Judith. Problemas de gênero: feminismo e subversão da identidade. Rio de Janeiro: Civilização Brasileira, 2010.

DURKHEIM, E. Lições de sociologia: a moral, o direito e o Estado. São Paulo, T. A. Queiroz/USP, 1983.

ENGELS, Friedrich. A origem da família, da propriedade privada e do Estado. 1 ed., prefacio p. XXVIII-XXIX, 1884.

GALLOP, Jane. Além do Falo. In: Cadernos Pagu. P. 267-287, 2001.

HIRATA, H. et al (org.). Dicionário Crítico do Feminismo. Editora UNESP : São Paulo, 2009.

HOLANDA, Karla; TEDESCO, Marina, Cavalcanti (org). Feminino e Plural: mulheres no cinema brasileiro. Campinas-SP: Papirus, 2017.

FOUCAULT, Michel. A Ordem do Discurso. Edições Loyola. São Paulo 2013.

FOUCAULT, Michel. Vigiar e Punir: nascimento da prisão. Petrópolis: Vozes, 1987.

JAMESON, Fredric. Pós-Modernismo: a lógica cultural do capitalismo tardio. 2.ed. São Paulo: Ática, 2001.

KEHL, Maria Rita. Deslocamentos do feminino: a mulher freudiana na passagem para a modernidade. $2^{\circ}$ ed. São Paulo: Boitempo, 2016.

KLANOVICZ, Luciana Rosar F.; CORREAA, Willian Bruno. Gênero, censura e pornochanchada no cinema brasileiro. In: FILHO Claudio Bertolli; AMARAL Muriel Emídio Pessoa do (organizadores). Pornochanchando: em nome da moral, do deboche e do prazer. São Paulo: Cultura Acadêmica, 2016.

LAURETIS, Tereza de. Através do espelho: mulher, cinema e linguagem. In: Estudos Feministas, 1993, ano 1, p. 96-122. 
LEAL, Wills. O Nordeste no cinema. João Pessoa: Ed. Universitária FUNAP/UFPB, 1982.

LEVY, Joanice. Female Gaze e a narrativa cinematográfica. In: Anais XII Congresso de Ciências da Comunicação região Centro-oeste. Goiânia, maio 2010.

MULVEY, Laura. Prazer visual e cinema narrativo. In: XAVIER, Ismail (org.). A experiência do cinema. 3 ed. Rio de Janeiro: Graal, 2003.

PESSOA, Fernanda. Histórias que o nosso cinema (não) contava. Filme, 2018.

SAFFIOTI, Heleieth I. B. Gênero, patriarcado, violência. 1.ed. São Paulo: Fundação Perseu Abramo, 2004.

SAFFIOTI, Heleieth I.b.. Contribuições feministas para o estudo da violência de gênero. Cadernos Pagu, [s.I.], n. 16, p.115-136, 2001.

SANTOS, Caroline Lima. O Cangaceiro o cineasta e o imaginário: a produção de representações do cangaço no cinema brasileiro (1950-1964). Dissertação (Mestrado). Universidade do Estado da Bahia, Programa de pós-graduação em História Regional e Local, 2010 - 2010.

SALES FILHO, Valter Vicente. Pornochanchada: doce sabor da transgressão. In: Comunicação e Educação. N. 3, São Paulo, p. 67 a 70, mai./ago. 1995.

SELIGMAN, F. O "Brasil é feito pornôs": o ciclo da pornochanchada no país dos governos militares. Tese (Doutorado em Comunicação) - Escola de Comunicação e Artes, Universidade de São Paulo, 2000.

SCOTT, Joan. Gênero. "Uma categoria útil de análise histórica". In: Educação e Realidade. Porto Alegre, n. 16, julho/dezembro de 1990.

SWAIN, Tania Navarro. Meu corpo é um útero? Reflexões sobre a procriação e a maternidade. In: http://www.tanianavarroswain.com.br/chapitres/bresil/utero.htm.

STAM, Robert. Introdução à teoria do cinema. Campinas: Ed. Papirus, 2003.

SANTOS, Ana Maria dos. Desenvolvimentismo, trabalho e reforma agrária no Brasil, 1950-1964. In: Tempo. No 7. 1999.

SILVA, Alberto. Cinema e humanismo. Rio de Janeiro: Editora Pallas, 1975.

TOLENTINO, Célia Aparecida Ferreira. O rural no cinema brasileiro. São Paulo: UNESP, 2001.

VEIGA, Ana Maria. Estéticas e Políticas de resistência no "cinema de mulheres" brasileiro (1970-1980), p. 77-88. In: HOLANDA, Karla; TEDESCO, Marina, Cavalcanti (org). Feminino e Plural: mulheres no cinema brasileiro. Campinas-SP: Papirus, 2017.

VIEIRA, Marcelo Dídimo Souza. O Cangaço no cinema brasileiro. Tese. (Doutorado em Multimeios) Campinas-SP: UNICAMPI, 2007.

\section{Notas de autoria}

Caroline de Araújo Lima é professora Assistente da Universidade do Estado da Bahia DCHT/XVIII, Doutoranda em Ciências Sociais pela UFBA, Mestre em História Regional 
e Local pela UNEB, Licenciada em História pela UNIJORGE. Bolsista FAPESB. E-mail: carolimasantos@gmail.com.

Como citar esse artigo de acordo com as normas da revista

LIMA, Caroline de Araújo. De passivas a heroínas, de órfãs a cangaceiras eróticas: um breve debate teórico sobre as mulheres sertanejas na pornochanchada. Sæculum Revista de História, v. 24, n 41, p. 373-388, 2019.

\section{Contribuição de autoria}

Não se aplica.

Consentimento de uso de imagem

Não se aplica.

\section{Aprovação de comitê de ética em pesquisa}

Não se aplica.

\section{Licença de uso}

Este artigo está licenciado sob a Licença Creative Commons CC-BY. Com essa licença você pode compartilhar, adaptar, criar para qualquer fim, desde que atribua a autoria da obra.

\section{Histórico}

Artigo recebido em 20/07/2019.

Artigo aprovado em 09/09/2019. 